Annihilating Difference 


\section{CALIFORNIA SERIES IN PUBLIC ANTHROPOLOGY}

The California Series in Public Anthropology emphasizes the anthropologist's role as an engaged intellectual. It continues anthropology's commitment to being an ethnographic witness, to describing, in human terms, how life is lived beyond the borders of many readers' experiences. But it also adds a commitment, through ethnography, to reframing the terms of public debate - transforming received, accepted understandings of social issues with new insights, new framings.

Series Editor: Robert Borofsky (Hawaii Pacific University) Contributing Editors: Philippe Bourgois (UC San Francisco), Paul Farmer

(Partners in Health), Rayna Rapp (New York University), and Nancy Scheper-Hughes (UC Berkeley)

University of California Press Editor: Naomi Schneider

I. Treice Dead: Organ Transplants and the Reinvention of Death, by Margaret Lock

2. Birthing the Nation: Strategies of Palestinian Women in Israel, by Rhoda Ann Kanaaneh

3. Annihilating Difference: The Anthropology of Genocide, edited by Alexander Laban Hinton

4. Pathologies of Power: Structural Violence and the Assault on Health and Human Rights, by Paul Farmer 


\title{
Annihilating Difference
}

The Anthropology of Genocide

\author{
EDITED BY \\ Alexander Laban Hinton
}

With a foreword by

Kenneth Roth

Human Rights Watch 
University of California Press

Berkeley and Los Angeles, California

University of California Press, Ltd.

London, England

(C) 2002 by The Regents of the University of California

Library of Congress Cataloging-in-Publication Data

Annihilating difference : the anthropology of genocide / edited by Alexander Laban Hinton ; with a foreword by Kenneth Roth.

p. cm.-(California Series in Public Anthropology; 3)

Includes bibliographical references and index.

ISBN 0-520-23028-o (Cloth : alk. paper).- ISBN o-520-23029-9

(Paper : alk. paper)

I. Genocide. 2. Ethnic conflict. I. Hinton, Alexander Laban.

II. Series.

HV6322.7 .A64 2002

$304.6^{\prime} 63-\mathrm{dc} 2 \mathrm{I}$

2001007073

Manufactured in the United States of America

$\begin{array}{llllllllll}\text { I0 } & 09 & 08 & 07 & 06 & 05 & 04 & 03 & 02\end{array}$

I0 $\quad 9 \begin{array}{lllllllll} & 8 & 7 & 6 & 5 & 4 & 3 & 2 & \text { I }\end{array}$

The paper used in this publication is both acid-free and totally chlorine-free (TCF). It meets the minimum requirements of ANSI/NISO Z39.48-I992 (R 1997) (Permanence of Paper). 